\title{
BENTUK DAN FUNGSI TUTURAN EKSPRESIF DALAM BAHASA PRANCIS
}

\author{
Siti Perdi Rahayu \\ Fakultas Bahasa dan Seni Universitas Negeri Yogyakarta \\ email: perdi_rahayu@yahoo.fr
}

\begin{abstract}
Abstrak
Penelitian ini bertujuan untuk mendeskripsikan bentuk, makna, dan fungsi tuturan ekspresif dalam bahasa Prancis. Pengumpulan data menggunakan metode simak dan catat. Metode agih digunakan untuk menganalisis bentuk tuturan ekspresif, sedangkan untuk fungsi tuturan ekspresif digunakan metode padan referensial. Hasil penelitian sebagai berikut. Pertama, bentuk dan makna tuturan ekspresif meliputi (a) tindak tutur langsung literal, (b) tindak tutur tidak langsung literal, (c) tindak tutur langsung tidak literal, dan (d) tindak tutur tidak langsung tidak literal. Kedua, fungsi tuturan ekspresif meliputi (a) mengucapkan selamat, (b) berterima kasih, (c) bersimpati/berbelasungkawa, (d) memuji, (e) meminta maaf, (f) mengritik, (g) mengeluh, dan (h) menyalahkan.
\end{abstract}

Kata kunci: tuturan ekspresif, bentuk dan makna tuturan ekspresif, fungsi tuturan ekspresif

\section{FORMS AND FUNCTIONS OF EXPRESSIVE UTTERANCES IN FRENCH}

\begin{abstract}
This study aims to describe forms, meanings, and functions of expressive utterances in French. The data were collected through listening and note-taking. The forms were analyzed by means of a substitution method and the functions by means of a referential correspondence method. The results are as follows. First, the forms and meanings of expressive utterances include (a) literal direct speech acts, (b) literal indirect speech acts, (c) non-literal direct speech acts, and (d) non-literal indirect speech acts. Second, the functions of expressive utterances include (a) congratulating, (b) thanking, (c) expressing sympathy/condolences, (d) complimenting, (e) apologizing, (f) criticizing, (g) complaining, and (h) blaming.
\end{abstract}

Keywords: expressive utterances, forms, meanings, functions

\section{PENDAHULUAN}

Agar komunikasi dapat berjalan dengan baik dan sesuai dengan keinginan para penuturnya, ada beberapa faktor yang dapat mempengaruhinya, yaitu siapa penutur, siapa mitra tutur, kapan dan di mana tuturan itu terjadi. Oleh karena itu, penggunaan bahasa sebagai alat komunikasi bersifat sangat variatif, artinya untuk mengungkapkan satu maksud seseorang bisa menggunakan bentuk tuturan yang bermacam-macam. Hal ini sesuai dengan pendapat Austin (1962) bahwa dalam suatu bentuk tuturan sebenarnya seseorang itu tidak hanya mengatakan sesuatu tetapi juga melakukan sesuatu.

Dalam berkomunikasi tidak selamanya berkaitan dengan masalah-masalah yang bersifat tekstual, tetapi juga interpersonal sehingga komunikasi verbal bentuk apapun perlu disikapi sebagai sebuah fenomena pragmatik, yaitu bagaimana satuan kebahasaan itu digunakan di dalam berkomunikasi atau berinteraksi antarmanusia. Apabila sebagai retorika tekstual, pragmatik membutuhkan prinsip kerja sama. Sebagai retorika interpersonal, pragmatik membutuhkan prinsip 
kesopanan (Wijana,1996:56). Untuk mencapai tujuannya, seorang penutur dalam bertindak tutur selalu berusaha agar hal yang disampaikan dapat dipahami dan tidak merugikan mitra tutur.

Menurut Searle (Wijana, 1996: 17 -22 Cummings, 2007: 9, dan Wijana dkk, 2010: 20-26) tindak tutur dapat dibedakan menjadi 3 macam yaitu: 1) tindak lokusi (locutionary act), 2) tindak ilokusi (ilocutionary act), dan 3) tindak perlokusi (perlocutionary act). Tindak lokusi adalah tindak tutur untuk menyatakan sesuatu (the act of saying something), sedangkan tindak ilokusi adalah tindak tutur untuk mengatakan sesuatu atau menginformasikan sesuatu dan sekaligus untuk melakukan sesuatu (the act of doing something). Adapun tindak perlokusi adalah tindak tutur yang pengutaraannya dimaksudkan untuk mempengaruhi lawan tutur.

Selanjutnya Searle (Ibrahim, 1993: 11 -54, dan Yule, 2006: 92-95, Rahardi, 2009: 17-18)) mengembangkan teori tindak tutur yang terpusat pada tindak ilokusi tersebut berdasarkan pada tujuan dari tindakan pandangan penutur. Selanjutya, tindak ilokusi dapat dibedakan lagi menjadi 5 jenis. Pertama, asertif (assertives), pada ilokusi ini penutur terikat pada kebenaran proposisi yang diungkapkan, misalnya, menyatakan, mengusulkan, membuat, mengeluh, mengemukakan pendapat, dan melaporkan. Kedua, direktif (directives), lokusi ini bertujuan menghasilkan suatu efek berupa tindakan yang dilakukan oleh penutur; misalnya, memesan, memerintah, memohon, menuntut, dan memberi nasihat. Ketiga, komisif (commissives), pada ilokusi ini penutur sedikit banyak terikat pada suatu tindakan di masa depan, misalnya, menjanjikan, menawarkan. Jenis ilokusi ini cenderung berfungsi menyenangkan dan kurang bersifat kompetitif karena tidak mengacu pada kepentingan penutur, tetapi pada kepentingan petutur (mitra tutur). Keempat, ekspresif (expressive), fungsi ilokusi ini ialah mengungkap atau mengutarakan sikap psikologis penutur terhadap keadaan yang tersirat dalam ilokusi, misalnya: mengucapkan terima kasih, mengucapkan selamat, memberi maaf, mengecam, memuji, mengucapkan belasungkawa, dan sebagainya. Kelima, deklarasi (declaration), berhasilnya pelaksanaan ilokusi ini akan mengakibatkan adanya kesesuaian antara isi proposisi dengan realitas Misalnya, mengundurkan diri, membaptis, memecat, memberi nama, menjatuhkan hukuman, mengucilkan/membuang, mengangkat.

Berdasarkan bentuknya, Wijana (1996: 29-36, Wijana: 2010: 27-35) membagi bentuk-tindak tutur menjadi dua jenis. Pertama, tindak tutur langsung, yaitu apabila ada hubungan langsung antara struktur dengan fungsi. Misalnya bentuk deklaratif digunakan untuk membuat pernyataan. Kedua, tindak tutur tidak langsung, yaitu apabila tidak ada hubungan langsung antara struktur dengan fungsi. Misalnya bentuk deklaratif digunakan untuk membuat permohonan. Berdasarkan maknanya bentuk tindak tutur dapat dibedakan menjadi 2 (dua), yaitu: (1) tindak tutur literal (literal speech act) adalah tindak tutur yang maksudnya sama dengan makna kata-kata yang yang menyusunnya, dan (2) tindak tutur tidak literal (nonliteral speech act) adalah tindak tutur yang maksudnya tidak sama dengan atau berlawanan dengan makna kata-kata yang menyusunnya (Yule, 2006: 95-96).

Sebagaimana fungsi bahasa yang disampaikan oleh Yakobson (dalam Sudaryanto, 1990: 12) tuturan ekspresif termasuk dalam fungsi emotif, yaitu fungsi bahasa sebagai pengungap keadaan emosi pembicara. Keadaan ini bisa berupa kesenangan, kegembiraan, kesedihan, dan sebagainya. Yule (2006:93) menyatakan tindak tutur ekspresif adalah tindak tutur yang menyatakan sesuatu yang dirasakan oleh penutur dan berfungsi untuk menunjukkan sikap psikologis penutur terhadap 
keadaan yang sedang dialami oleh mitra tutur. Tindak tutur ekspresif juga mencerminkan pernyataan-pernyataan kegembiraan, kesulitan, kesukaan, kebencian, kesenangan, atau kesengsaraan.

Setiap tuturan yang terjadi dalam suatu percakapan selalu melibatkan adanya konteks. Dengan konteks yang jelas, sebuah komunikasi akan berjalan dengan baik. Hymes (1972) menyusun kontekskonteks yang harus ada dalam suatu komunikasi ini dalam bentuk komponen tutur yang disingkat menjadi SPEAKING atau dalam bahasa Prancis PARLANT (P: Participant, A: Actes, R: Raison (Resultat), L: Local, A: Agents (Instrumentalies), N: Normes, T: Ton (Key), T: Types (Genres).

Sebagai bentuk kepedulian sosial, individu yang satu terhadap individu yang lain, bahasa dapat berfungsi untuk mengungkapkan isi hati penutur kepada mitra tutur, seperti yang terungkap dalam salah satu tujuan komunikasi tujuan, yaitu mengekspresikan. Kepedulian itu ditunjukkan penutur dengan menyampaikan atau mengucapkan sesuatu sesuai dengan keadaan atau kondisi mitra tutur, misalnya: ucapan selamat, ucapan belasungkawa, dan sebagainya. Dalam masyarakat Prancis ditemukan berbagai macam bentuk tuturan untuk maksud yang sama, seperti pada contoh berikut.

(1) Nous sommes ravis d'apprendre la naissance de votre petite fille.

'Kami sangat senang mendengar kelahiran putri kecil anda"

(2) Félicitations pour l'arrivée de votre petite fille!

'Selamat atas kehadiran putri kecil anda!"

(3) Pour la nouvelle maman. Meilleurs voeux à vous et votre fille.

'Sebagai mama baru. Selamat untuk anda dan putri kecil anda"

Tuturan (1), (2), dan (3) sebenarnya mempunyai tujuan atau maksud yang sama, yaitu mengucapkan selamat atas kelahiran seorang putri (bayi) 'la naissance de votre petite fille', 'l'arrivé de votre petite fille' atau mengucapkan selamat menjadi mama baru 'la nouvelle maman'. Namun kalau diperhatikan, tuturan (1), (2), dan (3) mempunyai bentuk yang berbeda-beda. Tuturan (1) berbentuk kalimat deklaratif atau kalimat berita, tuturan (2) berbentuk eksklamatif, sedangkan tuturan (3) berbentuk frase preposisional pour la nouvelle maman dan frasa nominal Meilleurs voeux à vous et votre fille

Contoh di atas merupakan salah satu bentuk dan fungsi tuturan ekspresif dalam bahasa Prancis. Penelitian ini mengkaji lebih dalam berbagai bentuk dan fungsi tuturan ekspresif dalam bahasa Prancis dengan berbagai permasalahannya yang muncul. Permasalahan tersebut terkait dengan bagaimana bentuk, makna dan fungsi tuturan ekspresif dalam bahasa Prancis

\section{METODE}

Data dalam penelitian ini adalah semua kata, frase, dan kalimat yang di dalamnya mengandung tuturan ekspresif. Data diambil dari sumber data yang terdiri dari: Buku Ajar Campus 1,2, dan 3, Majalah ELLE edisi 23 April 2007, 8 September 2007, 17 November 2008, 1 Desember 2008, 27 Desember 2008, Komik Spirou et Fantasio "Aventure en Australie" karya Tome \& Janry, Komik L'Agent 212 "Pas de panique karya Daniel Kox et Raoul Cauvin, Beberapa berita actual yang diunduh dari fr.news.yahoo.com, dan kartu ucapan yang terdapat dalam media cetak dan internet (http://www.merci-facteur. $\mathrm{com} /$ ), dan lain sebagainya.

Pada tahap penyediaan data, peneliti menggunakan metode simak untuk mengumpulkan data, yaitu metode yang dilakukan dengan cara menyimak penggunaan bahasa (Sudaryanto, 1993: 133) dengan teknik dasar teknik sadap dilanjutkan dengan teknik lanjutan SBLC (Simak Bebas Libat Cakap) dan teknik 
catat, yaitu mencatat semua data pada komputer. Dalam pengumpulan data ini peneliti membaca dengan seksama semua sumber data yang telah ditentukan, yaitu: beberapa surat dan email, majalah, koran, komik, dan kartu ucapan yang terdapat dalam media cetak dan internet, kemudian mencermati semua penggunaan kata, frase, dan kalimat yang mengandung tuturan ekspresif. Setelah data terkumpul kemudian diklasifikasikan berdasarkan: (1) bentuk dan (2) fungsi dari tuturan ekspresif tersebut. Berdasarkan bentuknya, tuturan ekspresif dapat diklasifikasikan menjadi: (1) tindak tutur langsung literal (direct literal speech act), (2) tindak tutur tidak langsung literal (indirect literal speech act), (3) tindak tutur langsung tidak literal (direct nonliteral speech act), dan (4) tindak tutur tidak langsung tidak literal (indirect nonliteral speech act). Berdasarkan fungsinya tuturan ekspresif dapat bertujuan untuk menyatakan ucapan: selamat, terima kasih, bersimpati/ berbelasungkawa, memuji, meminta maaf, mengkritik, mengeluh, dan menyalahkan.

Metode yang digunakan untuk menganalisis data adalah metode agih dan metode padan. Menurut Sudaryanto (1993: 13-15 dan Kesuma, 2007: 54) metode agih atau metode padan intralingual (Mahsun (2005: 111-115) adalah metode analisis bahasa yang alat penentunya adalah bagian dari bahasa yang bersangkutan itu sendiri. Sedangkan metode padan (Kesuma, 2007: 47) adalah metode analisis bahasa yang alat penentunya ada di luar, terlepas, dan tidak menjadi bagian dari bahasa (langue) yang bersangkutan. Mahsun (2005: 111-115) menyebut metode ini adalah metode pada ekstralingual. Metode agih (metode padan intralingua) digunakan untuk menganalisis bentuk-bentuk tuturan ekspresif, teknik yang digunakan adalah teknik dasar, yaitu teknik bagi unsur langsung (teknik BUL) dan teknik lanjutan, yang berupa teknik baca markah. Teknik BUL adalah teknik yang dilakukan dengan cara membagi data menjadi beberapa satuan lingual (konstituen) (Sudaryanto, 1993: 31).

Teknik baca markah adalah teknik analisis dengan melihat langsung pemarkah yang ada dalam suatu konstruksi (Sudaryanto, 1993: 95). Konstruksi yang dimaksud dalam penelitian ini adalah konstruksi tuturan-tuturan ekspresif, yang mungkin bisa berbentuk eksklamatif, yaitu yang berfungsi untuk menyatakan emosi maupun yang berbentuk selain eksklamatif, tetapi berfungsi menyatakan emosi.

Untuk mengetahui fungsi tuturan ekspresif digunakan metode padan referensial disertai dengan komponenkomponen tutur yang dikembangkan oleh Hymes, yaitu SPEAKING (Setting and scene, Participants, Ends, Act Sequence, Key, Isrumentalities, Norme of Interaction and Interpretation, dan Genre), yang dalam bahasa Prancis disingkat PARLANT ( $P$ : Participant, A: Actes, R: Raison (Resultat), L: Local, A: Agents (Instrumentalies), N: Normes, T: Ton (Key), T: Types (Genres). Untuk selanjutnya dalam analisis data digunakan istilah yang ada dalam bahasa Prancis, yaitu PARLANT.

Uji validitas data yang digunakan adalah validitas semantis, yaitu mengukur tingkat kesensitifan suatu teknik terhadap makna-makna simbolik yang relevan dengan konteks tertentu. Makna semantis dapat dicapai apabila makna-makna tersebut berhubungan dengan penerima pesan, sumber pesan, isi pesan, dan konteks lainnya dari data-data yang dianalisis (Darmiyati, 1993:75). Sedangkan uji reliabilitas adalah stabilitas yang didukung expert judgement, yaitu peneliti membaca berulang-ulang tuturan-tuturan ekspresif, dan apabila terdapat keraguan, peneliti berdiskusi dengan sesama dosen yang serumpun bidang ilmu atau dengan dosen senior atau ahli yang lebih menguasai bidang tersebut ((Darmiyati, 1993:79). 


\section{HASIL DAN PEMBAHASAN}

Sesuai dengan permasalahan penelitian, pada bagian ini disajikan hasil penelitian berkaitan dengan tuturan ekspresif dalam bahasa Perancis mencakup dua hal, yaitu (a) bentuk dan makna tuturan ekepresif dan (b) fungsi tuturan ekspresif.

\section{Bentuk Tuturan Ekspresif dalam Bahasa Prancis}

Berdasarkan bentuk dan makna, tuturan ekspresif dalam bahasa Prancis dapat dibedakan menjadi 4 (empat), yaitu: (1) tindak tutur langsung literal, (2) tindak tutur tidak langsung literal, (3) tindak tutur langsung tidak literal, dan (4) tindak tutur tidak langsung tidak literal.

\section{Tindak Tutur Langsung Literal}

Tindak tutur langsung literal (direct literal speech act), adalah tindak tutur yang diutarakan dengan modus tuturan dan makna yang sama dengan maksud pengutaraannya, misalnya: maksud memerintah disampaikan dengan kalimat perintah, memberitakan dengan kalimat berita, menanyakan sesuatu dengan kalimat Tanya, dan sebagainya. Hal tersebut dapat dilihat pada contoh berikut ini:

(1) Arthur a mal car son régime donc il ne peut pas continuer sa tâche.

Albert: Retourne chez toi Arthur, je vais prendre ta place. Peut-être que demain ça ira mieux...

Arthur: Albert! Tu es un frère pour moi !M...merci! Snirf!

'Arthur tidak enak badan karena sedang berdiet sehingga ia tidak bisa melanjutkan tugasnya.

Albert: Pulanglah Arthur, aku akan menggantikanmu. Semoga besok sudah sehat kembali....

Arthur: Albert, kau memang saudaraku...terima kasih'
Konteks:

Arthur dan Albert sedang mengerjakan tugas, tetap Albert melihat wajah Arthur pucat. Kemudian Albert menyuruh Arthur untuk pulang saja dan beristirahat agar esok harinya bisa bekerja kembali. Dan Arthur tidak perlu khawatir atas tugas-tugasnya, karena Albert bersedia menggantikannya sementara Arthur tdak ada.

Tuturan (1) yang disampaikan oleh Arthur: Albert! Tu es un frère pour moi ! M...merci! Snirf! merupakan bentuk eksklamatif yang sekaligus juga mengandung makna ekspresif, yaitu makna yang dimaksukan untuk menyatakan ucapan terima kasih, yaitu ucapan terima kasih Arthur kepada Albert, karena Albert telah menggantikan pekerjaan Arthur. Bentuk dan makna seperti ini disebut sebagai bentuk tuturan langsung literal

(2) Félicitations pour tes fiançailles!

Selamat atas pertunangan kalian!"

Konteks:

Seseorang menyampaikan ucapan selamat kepada temannya yang sedang melaksanakan pertunangannya

Tuturan (2) Félicitations pour tes fiançailles! adalah tuturan yang berbentuk eksklamatif dan bermakna ekspresif, yaitu tuturan yang dimaksudkan untuk menyampaikan ucapan selamat, yaitu selamat atas pertunangan sahabatnya yang sedang melaksanakan pertunangan. Tuturan yang bermaksud ekpresif (menyampaikan selamat) diungkapkan dengan kalimat ekslamatif seperti ini disebut tuturan langsung literal.

\section{Tindak Tutur Tidak Langsung Literal,}

Tindak tutur tidak langsung literal (indirect literal speech act), adalah tindak tutur yang diungkapkan dengan modus kalimat yang tidak sesuai dengan maksud pengutaraannya,tetapi makna kata-kata yang menyusunnya sesuai dengan makna 
kata yang dimaksudkan penuturnya, contoh:

(3) Je vous souhaite le meilleur pour vos fiançailles et tout ce qui vous attend.

“Saya berharap semua yang terbaik untuk pertunangan anda dan juga untuk semua yang anda harapkan"

Konteks:

Seseorang menyampaikan ucapan selamat kepada temannya yang baru saja melaksanakan pertunangannya

Tuturan (3) merupakan tuturan yang berbentuk kalimat berita, tetapi maksud yang ingin disampaikan bukanlah memberikan informasi atau menyampaikan berita. Maksud yang ingin disampaikan melalui kalimat berita ini adalah subjek Je mengucapkan selamat atas pertunangan vous disertai dengan harapan-harapan yang terbaik. Tuturan yang berbentuk kalimat berita tetapi dengan maksud menyampaikan ucapan selamat ini disebut tuturan tidak langsung literal.

\section{Tindak Tutur Langsung Tidak Literal,}

Tindak tutur langsung tidak literal (direct nonliteral speech act), adalah tindak tutur yang diutarakan dengan modus kalimat yang sesuai dengan maksud tuturan, tetapi kata-kata yang menyusunnya tidak memiliki makna yang sama dengan maksud penuturnya, misalnya maksud memerintah diungkapkan dengan kalimat perintah, dan maksud menginformasikan dengan kalimat berita, dan sebagainya.

(4) Monsieur le capitaine: ... alors vous, vous êtes censés arrêter les déserteurs! Vous restez derrière les lignes, et le premier qui se débine, crac, dedans!

Albert: Bien, mon capitaine!

Arthur (à Albert): Mais c'est complètement idiot!

Albert: Bah! C'est ça. Les grandes mancuvres! Il faut jouer le jeu! Faire semblant quoi! (L'Agent 212 «Pas de panique » page 41)
Kapten: ...dan kalian, kalian seharusnya berada di belakang para serdadu! Kalian tetap di garis akhir dan awasi siapa yang pertama kabur!

Albert: Baik kapten !

Arthur (kepada Albert) : Ini benarbenar bodoh !

Albert: Bah ! Seperti inilah latihan perang. Mereka harus memainkannya seperti perang sesungguhnya!

Konteks:

Dalam suasana latihan perang, Kapten (Monsieur le capitaine) memberikan tugas kepada Albert dan Arthur untuk mengawasi para serdadu, dan mereka harus memberikan laporan kepada kapten siapa yang pertama kali kabur. Tetapi Arthur tidak suka tugas tersebut sambil mengeluh, sedang Albert dapat menerima tugas itu dengan baik.

Tuturan Arhur kepada Albert pada dialog (1) di atas Mais c'est complètement idiot! merupakan tuturan langsung artinya bentuk dari tuturan itu adalah berupa kalimat eksklamatif untuk menyatakan ekspresi mengeluh, tetapi dilihat dari makna kata-kata yang yang menyusunnya bukanlah kata-kata yang bermakna mengeluh, Mais c'est complètement idiot «tetapi ini benar-benar bodoh'. Jadi dalam tuturan tersebut tidak ada kata-kata yang bermakna mengeluh, namun jika dilihat dari konteksnya tuturan tersebut bermakna mengeluh, yaitu bahwa Arthur tidak suka menerima tugasnya, sehingga dia mengeluh dengan mengatakan Mais c'est complètement idiot!. Tuturan seperti ini disebut tuturan langsung tidak literal.

\section{Tindak Tutur Tidak Langsung Tidak Literal}

Tindak tutur tidak langsung tidak literal (indirect nonliteral speech act) adalah tindak tutur yang diutarakan dengan modus kalimat dan makna kalimat yang tidak sesuai dengan maksud yang hendak diutarakan. Perhatikan contoh di bawah ini. 
(5) $\mathrm{NON}$

«Barack Obama a mené un campagne remarquablement efficace. Il n'est pas là grâce à un personnage de télé.» (Robert Thompson)

\section{'TIDAK SETUJU}

«Barack Obama telah menyelesaikan kampanye yang benar-benar luar biasa. Hal itu bukan karena tokoh dalam televisi. » (Robert Thompson)'

Konteks:

Robert Thompson memberikan komentar tidak setuju pada sebuah artikel di majalah ELLE yang menyebutkan bahwa Obama menang pemilu karena adanya serial televisi. Menurut Robert Thompson Obama menang dalam pemilu buakan karena serial televisi, melainkan karena Obama telah dapat menyelesaikan kampanyenya dengan benar-benar luar biasa.

Tuturan yang disampaikan oleh Robert Thompson pada artikel di atas merupakan tuturan tak langsung, artinya tuturan tersebut berbentuk kalimat berita, tetapi maksud dari kalimat berita itu bukanlah memberitakan/menginformasikan sesuatu, melainkan bertujuan untuk menyalahkan (tidak setuju). Jika dilihat dari unsur-unsur/kata-kata yang membentuknya, tuturan tersebut tidak juga tersusun atas kata-kata yang bermakna menyalahkan. Tuturan yang demikian itu disebut tuturan tudak langsung tidak literal.

\section{Fungsi Tuturan Ekspresif}

Berdasarkan fungsi tuturan ekspresif dalam bahasa prancis dapat dibedakan menjadi 8 (delapan), yaitu berfungsi untuk: mengucapkan selamat, berterima kasih, bersimpati/berbelasungkawa, memuji, meminta maaf, mengkritik, mengeluh, menyalahkan. Berikut ini dijelaskan bentuk dan fungsi tuturan yang telah ditemukan. Dari data-data yang terkumpul, tuturan-tuturan ekspresif dalam bahasa Prancis berdasarkan fungsinya dapat diklasifikasikan menjadi, yaitu (1) mengucapkan selamat, (2) berterima kasih, (3) bersimpati/berbelasungkawa, (4) memuji, (5) eminta maaf, (6) mengkritik, (7) mengeluh, dan (8) menyalahkan.

Tuturan ekspresif yang bertujuan untuk mengcapkan selamat ini meliputi: ucapan selamat atas keberhasilan sesorang, ucapan selamat ulang tahun, ucapan selamat tahun baru, ucapan selamat menempuh hidup baru, dan lain-lain. Berikut ini salah satu contoh ucapan selamat atas keberhasilan Julie dalam pentas teater.

(6) Chère Julie,

Ce petit mot pour te dire que je suis allée te voir jouer dans "Le Malade imaginaire ». Je te félicite. Tu as été parfaite! J'espère te voir bientôt chez ta grand-mère. Je t'embarrasse. Lina

'Julie sayang,

Memo ini untuk memberitahumu bahwa aku datang ke pertunjukan « Le Malade imaginaire ». Selamat. Kamu sangat sempurna. Kuharap kita bisa segera bertemu di rumah nenekmu. Sampai jumpa' Lina

Konteks tuturan (6) dapat dijelaskan sebagai berikut $\mathrm{P}$ (Participant) dalam surat di atas adalah Lina dan Julie, A (Actes): membicarakan tentang penampilan seseorang (Julie) yang bagus dalam pertunjukan théatre 'Le Malade Imaginaire', $\mathrm{R}$ (Raison/Resultat) : mengucapkan selamat dan atau memuji, L (Local): tempat pertunjukan (Café théatre), A (Agent) : memo (ce petit mot) yang menggunakan bahasa tulis, N (Normes): menunjukan apresiasi yang tinggi terhadap penampilan Julie, $\mathrm{T}$ (Tons/Types) : situasi senang dan kagum. Berdasarkan konteks yang menyertai, tuturan Je te félicite. Tu as été parfaite! 'Selamat. Kamu sangat sempurna' bertujuan menyatakan / menyampaikan ucapan selamat. 
Tuturan ekspresif juga dapat menyatakan fungsi berterima kasih, sebagaimana dapat dilihat pada contoh tuturan berikut ini.

(9) Un jour qui est très épais, il y a une collision en chaîne sur La Nationale 27 donc monsieur le commissaire envoi les ambulances disponibles. Le chauffeur d'une ambulance: Heureusement que le brouillard commence à se lever! On y verra plus clair

'Suatu hari dimana kabut sangat tebal, terjadi tabrakan berantai di Jalan La Nationale nomor 27 sehingga komisaris polisi mengirimkan mobil-mobil ambulans yang tersedia. Sopir salah satu mobil ambulans: Untungnya, kabut mulai menghilang. Suasana akan kembali terang'

Konteks yang menyertai tuturan heuresement dapat diuraikan sebagai berikut: P: Komisaris polisi dan sopir ambulans, A: pembicaraan umum tentang keadaan lingkungan yang berkabut, R: bersyukur, L: di jalan menuju La Nationale nomor 27, A: bahasa lisan, $\mathrm{N}$ : bersyukur karena memperoleh hal yang baik, T: senang. Berdasarkan konteks yang menyertainya kata heureusement 'untungnya' bertujuan untuk menyampaikan ucapan terima kasih atau ekspresi kelegaan, karena suasana pada waktu itu sudah mulai terang, kabut semakin menghilang, sehingga perjalanan menuju ke tempat lokasi kecelakaan untuk menolong para korban dapat berjalan dengan lancar .

Berikut ini adalah contoh tuturan ekspresif yang bertujuan untuk menyatakan bela sungkawa atas kematian seseorang.

(10) Nous sommes sous le choc de la nouvelle de la mort soudaine de votre père et nous voudrions vous offrir toute notre compassion
'Kami sangat terkejut atas berita meninggalnya ayahanda secara mendadak, dan kami sampaikan turut berduka cita yang sedalam-dalamnya kepada anda sekeluarga'

Tuturan (10) merupakan tuturan ekspresif yang bertujuan untuk menyatakan belasungkawa. Hal dapat dipahami dari konteks yang menyertainya, yaitu berupa komponen-komponen yang meliputi : P: nous 'kami' dan vous 'anda', A: terkejut karena mendengar kematian tiba-tiba ayah dari sahabatnya, R: berbela sungkawa, L: di sebuah apartemen, A: bahasa lisan / bahasa tulis, N: peduli terhadap kesedihan orang lain, T: sedih, berduka. Berdasarkan komponen-komponen yang membentuk knteks itulah, tuturan (10) bertujuan untuk menyatakan belasungkawa atau duka cita 'Nous' kepada 'vous' atas meninggalnya ayah dari 'vous' secara mendadak.

Tuturan ekspresif dapat juga berfungsi untuk menyampaikan pujian atau memuji atas perbuatan orang lain. Contoh tuturan yang dapat menyatakan pujian tersebut dapat dilihat pada kalimat berikut ini :

(11) Il y a un homme qui fait la grève de la faim pour que sa femme revient de Siberie. L'ami de personne qui fait la grève: Bravo mon vieux! Votre action a reussi! Votre femme a été libérée! Elle vous attend à l'aeroport! Venez, on vous emmène... (L'Agent 212 « Pas de panique » page 24)

'Seorang laki-laki melakukan mogok makan agar istrinya dipulangkan dari Siberia. Rekan laki-laki yang mogok makan: Bagus kawan! Tindakanmu sudah cukup. Istrimu telah dibebaskan. Ia menunggumu di bandara. Ayo, kuantarkan....'

Konteks yang menyertai tuturan ekspresif Bravo mon vieux! 'Bagus 
kawanku!' pada contoh (11) dapat dijelaskan sebagai berikut P: seorang laki-laki dan temannya, A: pembicaraan mengenai dukungan untuk teman yang kesusahan, R: memuji, L: di pinggir salah satu jalan raya, $\mathrm{A}$ : bahasa lisan, $\mathrm{N}$ : saling tolong menolong, T: senang. Berdasarkan konteks yang menyertainya tuturan Bravo mon vieux! bertujuan untuk memuji, yaitu seorang teman memuji perbuatan seorang suami yang melakukan mogok makan agar istrinya dipulangkan dari Siberia.

Tuturan meminta maaf dilakukan biasanya ketika seseorang melakukan kesalahan, baik kesalahan itu disengaja maupun tidak disengaja. Tuturan (12) di bawah ini merupakan salah satu contoh penggunaan tuturan ekspresif yang bertujuan meminta maaf.

(12) Mon cher Patrick,

Je suis vraiment désolée. Je te rends ce roman de PhilipeDelerin avec beaucoup de retard.

Je te prie de m'excuser, à bientôt. Mariane (Campus 1, page 99)

'Sahabatku Patrick,

Aku benar-benar menyesal. Aku sangat terlambat mengembalikan novel karya Philippe Delerin milikmu.

Aku benar-benar minta maaf. Sampai jumpa Mariane'

Tuturan ekspresif Je te prie de m'excuser 'Aku benar-benar minta maaf' terdapat dalam sebuah surat antar sahabat, secara kontekstual dapat dapat diuraikan sebagai berikut : $\mathrm{P}$ dalam suarat itu adalah Mariane dan Patrick, A: pembicaraan tentang kesalahan yang dilakukan, R: meminta maaf, L: di rumah Patrick, A: memo, bahasa tulis, $\mathrm{N}$ : berani meminta maaf jika berbuat salah, T: menyesal, merasa bersalah.

Jadi berdasarkan konteks yang menyertainya, tuturan Je te prie de m'excuser dapat berfungsi meminta maaf. Dalam konteks ini Mariane meminta maaf kepada Patrick, karena telah melakukan kesalahan, yaitu terlambat mengembalikan novel karya Philippe milik Patrik. Sehingga dia perlu meminta maaf kepada Patrik.

Tindak tutur yang berfungsi mengkritik dilakukan seseorang untuk menyatakan ketidaksukaannya, ketdakcocokannya, dan kecintaannya terhadap orang lain, sehingga perlu memberikan kritik/ saran/masukan. Tuturan ((13) di bawah ini merupakan salah satu contoh tuturan mengkritik karena tidak suka.

(13) Arthur et Albert rencontrent une voiture qui est conduit très vite.

Arthur: Bon sang il est complètement cinglé ce type! il fait au moins 220! Tu as vu que c'était?

Albert: Un peu, oui! Je vais avertir l'autre patrouille! Il faut absolument le coincer! (L'Agent 212 « Pas de panique » page 32)

'Arthur dan Albert berpapasan dengan mobil yang melaju sangat cepat.

Arthur: Bagaimana sih, orang itu benar-benar sinting! Kecepatannya hampir 220 kilometer per jam! Kau lihat kan?

Albert: Ya sekilas! Aku akan memberitahu petugas patroli lain! Mereka harus menghentikannya!'

Tuturan Bon sang il est complètement cinglé ce type ! yang terdapat dalam dialog (13) mempunyai konteks yang terdiri atas beberapa komponen, yaitu P: Albert dan Arthur, A: pembicaraan tentang pelanggaran aturan oleh seseorang, R: mengkritik, L: di sebuah jalan, A: bahasa lisan, N: mematuhi aturan yang berlaku, T: kesal, tidak setuju. Berdasarkan komponenkomponen itulah, tuturan Bon sang il est complètement cinglé ce type! dapat dikategorikan pada tuturan yang bertujuan untuk menyampaikan kritikan. Kritikan 
yang dimaksud adalah ketika Arthur dan Albert berpapasan dengan mobil yang melaju dengan sangat cepat, sehingga Arthur melontarkan tuturan kritikan tersebut, karena kecepatannya luar biasa cepat, $220 \mathrm{~km}$ per jam,

Tuturan mengeluh dapat terjadi karena rasa tidak puas/tidak sesuai dengan keinginan dalam diri seseorang. Dia tidak kuat menahan apa yang dirasakan, sehingga keluarlah tuturan-tuturan keluhan tersebut. Contoh :

(14) Une nuit quand la pluie tombe, un homme appelle la police parce qu'il y a de bruit chez son voisin. Quelques temps après, l'agent Arthur arrive chez lui.

L'homme qui a appelé le police: Ah! Enfin! Vous voilà... il y a plus deux heures que ça chaute là-haut...

(L'Agent 212 « Pas de panique » page 9)

Suatu malam pada saat hujan turun, seorang bapak yang tinggal di apartemen menghubungi polisi karena terjadi keributan di rumah tetangganya. Beberapa saat setelah menelepon, opsir Arthur datang ke tempat tinggal bapak tersebut.

Bapak yang menghubungi polisi: Akhirnya anda datang! Sudah sejak dua jam lalu mereka berbuah gaduh di lantai atas...

Tuturan il y a plus deux heures que ça chaute là-haut..., disertai konteks yang berupa komponen-komponen: P: salah satu penghuni apartemen dan opsir Arthur, A: pembicaraan tentang keluhan tentang tetangga yang membuat gaduh, R: berterimakasih karena polisi akhirnya datang, L: di sebuah apartemen, A: bahasa lisan, N: sigap menolong orang lain, $\mathrm{T}$ : senang, lega.

Sesuai dengan konteks yang menyertainya, tuturan il y a plus deux heures que ça chaute là-haut...'! Sudah sejak dua jam lalu mereka berbuah gaduh di lantai atas...' bertujuan untuk menyatakan sebuah keluhan, yaitu seorang lakilaki penghuni sebuah apartemen melapor kepada polisi karena merasa terganggu oleh kelakuan tetangganya yang selalu membuat keributan.

Tuturan ekspresif dapat berfungsi untuk menyalahkan, seperti pada contoh tuturan (15) berikut ini.

(15) Albert et Arthur en train de patrouille. Il y a un bruit quand ils passent une rue. Albert: Oh !? Arthur! Il se passe quelque chose là-bas!

Arthur: ?!

Arthur approche les deux homme qui se disputent.

Arthur: Qu'est-ce qui se passe ici ?

L'homme 1: Il se passe que ce*\#@ d'abruti à freine comme un *E\% au milieu de la route et que je suis rentre dedans!

(L'Agent 212 « Pas de panique » page 17)

Albert dan Arthur sedang bertugas patroli. Di salah satu jalan yang mereka lewati terjadi sebuah keributan.

Albert: Arthur, sepertinya terjadi sesuatu di sana!

Arthur pun mendekati dua laki-laki yang sedang bertengkar.

Arthur: Apa yang terjadi bapakbapak?

Laki-laki 1: Ini terjadi karena orang *\#@ ini mengerem mendadak di tengah jalan seperti seekor * $\& \%$ dan menyebabkan saya menabrak!

Tuturan Il se passequece *\#@ d'abruti à freine comme un ${ }^{*} \mathcal{E} \%$ au milieu de la route et que je suis rentre dedans! dalam dialog (22) memiliki konteks yang terdiri atas beberapa komponen yaitu : P: arthur, Albert dan dua laki-laki pengendara mobil, A: pembicaraan tentang peristiwa tabrakan yang terjadi tiba-tiba karena salah satu pengendara mobil mengerem 
mendadak di tengah jalan, R: menyalahkan, L: di sebuah ruas jalan, A: bahasa lisan, N: tidak berbuat gaduh di tempat umum, mematuhi aturan yang berlaku, T: marah.

Berdasarkan komponen-komponen yang membentuk konteks tuturan di atas, Il se passe que ce*\#@ d'abruti à freine comme un $* \mathcal{E} \%$ au milieu de la route et que je suis rentre dedans! merupakan tuturan ekspresif yang bertujuan untuk menyalahkan orang lain dalam peristiwa kecelakaan : pengendara mobil menyalahkan pengendara mobil yang ada di depannya mengerem terlalu mendadak.

\section{SIMPULAN}

Berdasarkan analisis data yang telah dilakukan, dapat disimpulkan beberapa hal sebagai berikut. Pertama, tuturan ekspresif dalam bahasa Prancis dapat disampaikan dengan berbagai bentuk tuturan, yaitu (1) tindak tutur langsung literal (direct literal speech act), (2) tindak tutur tidak langsung literal (indirect literal speech act), (3) tindak tutur langsung tidak literal (direct nonliteral speech act), dan (4) tindak tutur tidak langsung tidak literal (indirect nonliteral speech act). Kedua, tuturan ekspresif dalam bahasa Prancis dapat berfungsi untuk menyatakan: mengucapkan selamat, berterima kasih, bersimpati/berbelasungkawa, memuji, meminta maaf, mengkritik, mengeluh, dan menyalahkan. Ketiga, tuturan yang banyak ditemukan adalah tuturan ekspresif yang menyatakan fungsi berterima kasih, dan mengucapkan selamat, dan paling sedikit adalah fungsi menyalahkan. Hal itu mengimplikasikan bahwa dalam budaya masyarakat Prancis, orang lebih mudah mengucapkan terima kasih dan mengucapkan selamat kepada mitra tuturnya, dibandingkan dengan mencaricari kesalahan atau menyalahkan orang lain (mitra tutur)

\section{UCAPAN TERIMA KASIH}

Artikel ini disarikan dari hasil penelitian mandiri yang dilaksanakan di Fakultas Bahasa dan Seni pada tahun 2011 dengan anggaran dana DIPA FBS UNY tahun 2011. Ucapan terrima kasih kami sampaikan kepada DPP Penelitian FBS UNY yang telah memfasilitasi penelitian ini hingga selesai. Ucapan terima kasih juga kami sampaikan kepada Mugi Artianti, mahasiswa Jurusan Pendidikan Bahasa Prancis yang telah membantu pelaksanaan penelitian ini, dan juga kepada reviewer yang telah mengoreksi dan memberi masukan terhadap artikel ini.

\section{DAFTAR PUSTAKA}

Austin, J.L. 1962. How to Do Things with Words. (ed. J.O. Urmson). New York: Oxford University Press.

Cummings, Louise. 2007. Pragmatik: Sebuah Perspektif Multidisipliner. Yogyakarta: Pustaka Pelajar

Darmiyati Zuchdi. 1993. Panduan Penelitian Analisis Konten. Yogyakart: Lemlit IKIP Yogyakarta.

Kridalaksana, Harimurti. 2008. Kamus Linguistik. Jakarta: PT Gramedia.

Ibrahim, Abdul Syukur. 1993. Kajian Tindak Tutur. Surabaya: Usaha Nasional

Kesuma, Tri Mastoyo Jati. 2007. Pengantar (Metode) Penelitian Bahasa. Yogyakarta: Caraswatibooks

Leech, Geoffrey. 1993. Prinsip-prinsip Pragmatik. Terjemahan M.D.D. Oka. Jakarta: Universitas Indonesia.

Mahsun, MS. 2005. Metode Penelitian Bahasa: Tahapan, Strategi, Metode dan Tekniknya. Jakarta: Rajawali Pers

Rahardi, Kunjana. 2009. Sosiopragmatik. Jakarta: Erlangga

Searle, John R. 1969. Speech Acts: An Essay in The Philosophy of Language. Cambridge: Cambridge University Press.

Sudaryanto. 1990. Menguak Fungsi Hakiki Bahasa. Yogyakarta: Duta Wacana University Press 
Sudaryanto. 1993. Metode dan Aneka Teknik Analisis Bahasa: Pengantar Penelitian Wacana Kebudayaan secara Linguistis. Yogyakarta: Duta Wacana University Press

Wijana, I Dewa Putu. 1996. Dasar-dasar Pragmatik. Yogyakarta: Penerbit Andi
Wijana, I Dewa Putu dan Muh Rohmadi. 2010. Analisis Wacana Pragmatik: Kajian Teori dan Analisis. Surakarta: Yuma Pustaka

Yule, George. 2006. Pragmatik. Terjemahan Indah Fajar Wahyuni.Yogyakarta: Pustaka Pelajar. 